\title{
Reading Illness in Leo Tolstoy's The Death of Ivan Ilych: Perspectives on Literature and Medicine
}

\author{
Shadi S. Neimneh ${ }^{1}$, Marwan M. Obeidat ${ }^{1} \&$ Kamal E. Bani-Hani ${ }^{1}$ \\ ${ }^{1}$ English Department, Hashemite University, Zarqa, Jordan \\ Correspondence: Shadi S. Neimneh, English Department, Hashemite University, Zarqa, Jordan. E-mail: \\ shadin@hu.edu.jo
}

$\begin{aligned} & \text { Received: October 28, } 2015 \quad \text { Accepted: December 10, } 2015 \quad \text { Online Published: February 26, } 2016 \\ & \text { doi:10.5539/ells.v6n1p59 }\end{aligned}$ URL: http://dx.doi.org/10.5539/ells.v6n1p59

\begin{abstract}
This article seeks to establish the ambiguous nature of Ivan Ilych's illness in Leo Tolstoy's novella The Death of Ivan Ilych (1886), and it then proceeds to offer sociocultural commentary on an incurable illness that results in the death of the title character. Regardless of the exact nature of Ivan Ilych's illness, however, the story suggests that Ivan lived the "wrong" kind of life despite his self-deception and the lies of those around him. Some readers might be intrigued by the mysterious ailment of Ivan Ilych that aggravates into an agonizing death, and some might read the story as a pathography and ponder the doctors' possible diagnoses alluded to in the text like a floating kidney, a vermiform appendix or a chronic catarrh. While others, on the other hand, might argue for alternative illnesses (not mentioned in the text) allowing for a case like cancer. However, reading the story as a parable to be decoded by physicians using medical expertise does not do justice to its symbolic engagement with illness. It is argued that the text seems to favor a reading that connects ailment to the lifestyle one is following and to one's own personality or social class. In this regard, the article works at the intersection between the humanities and "medical theories" as adapted for literary ends. Ivan Ilych led the wrong form of life in his pursuit of wealth and hypocritical relations. Therefore, his terminal illness - read as a form of pancreatic cancer-is a figure for an "unhealthy" upper middle-class life lived at the wrong side emotionally, socially and physically. Within the interdisciplinary approach of this article, the metaphorical significance of illness is more important than specifying the exact illness that eventually causes Ivan Ilych's death because this illness is significantly symbolic beyond its literal sense. Therefore, the symbolic representation/understanding of illness - of cancer in particular - as a social blight or a scourge related to social behavior is insightful for physicians and patients alike.
\end{abstract}

Keywords: Leo Tolstoy, The Death of Ivan Ilych, Literature vs. Medicine, illness, metaphor, social criticism, cancer

\section{Introduction}

\subsection{The Novella in Context}

The literature of the sick and the dying is becoming an increasingly rich field of literary and cultural analysis and is drawing the attention of both critics and medical practitioners alike. Fictional and non-fictional variations on the genre of illness narrative have flourished recently. Moreover, literary works presented from the perspective of doctors like William Carlos Williams's short story "The Use of Force" and Franz Kafka's "A Country Doctor" have, as examples, made a good impact on medical students and doctors alike. On the other hand, literary works depicting different forms of physical as well as mental illnesses abound. Thomas Mann's The Magic Mountain (1924) and Virginia Woolf's Mrs. Dalloway (1925) are just two well-known examples of the literary works treating physical, mental illness respectively, and offering insights on the intersection between medicine and the humanities as a field of knowledge.

To be sure, Leo Tolstoy's novella The Death of Ivan Ilych (1886) is a late $19^{\text {th }}$ century meditation on the meaning of life and the inevitability of death after chronic illness. Most critics have examined this novella's social, moral, and religious themes. Only very few of them have examined its medical orientation including the relationship between the literary text and medical studies as such. According to Mary Beard (2015), the novella is "a memorable reflection" on the theme of "the point of living" in the face of a certain death. Beard argues that Ivan Ilych, a dying man beyond cure, is confronted with "the agony, indignity, loneliness, and ... foul stench of his 
own demise." Another critic has seen the story as "a hard, pitiless stare into the abyss, not just of death, but of human nature" (Lezard, 2015). Jerome Donnelly (2013) argues the satirical and religious aspects of the novella (using a critical examination of the novella's criticism of denial) and asserts that Ivan Ilych "has kept that reality at bay by implicitly regarding death as something that happens to other people," but not to him (p. 73). For Steven Feldman (2004), for instance, Ivan Ilych's professional life has kept him from the moral ends he should have pursued in his life prior to his illness and eventually death. Thus, as far as Ivan Ilych and his professional group are concerned, the novella shows little "moral development" beyond "the organizational conformity needed to pursue their self-interests" (Feldman, p. 312). Ivan Ilych is a middle-aged, middle-class man anxious about better living conditions but trapped in a frustratingly conventional life. Hence, Michael Verno (2009) describes him as a "shallow and conforming protagonist" who refuses to consider the end that will come with time (p. 123). Leland Ryken argues that one purpose behind the work is to "jolt readers out of living by the shallow norms of modern society and to lead them to face the serious and unavoidable issues of life and death." Mark Freeman (1997), in a study on how examining ageing can contribute to leading a good life, suggests that the story represents "the grave consequences of a life lived moment to moment, without any sense of the whole", i.e., without considering the end that is death or contingent situations like illness (p. 373). And other critics found Ivan Ilych to be a self-deceiving, and thus hypocritical, character who falsely thinks that he can get well and escape death (Widyaningrum \& Khoiri, 2014). Victor Brombert (2006), for one, looks at "the clinical realities of dying" reading the story as "a meditation on mortality" (p. 152).

Such analyses of the novella, though subtle and complex-in-demands, have not examined the nature of Ivan Ilych's illness or the figurative employment of this illness to project such social, moral and religious aspects of the text critics have often underscored. Hence, most critics have highlighted the social aspect of the story or its existential treatment of the inevitability of death. For example, Lehto and Stein (2009) have described Ivan Ilych's life as "egocentric, seemingly meaningless existence" (p. 23). To use the descriptive words of another, Ivan Ilych has lived as "a vicious bureaucrat" and his whole life is "defined by the rigid bureaucratic society" (Wiseman, 2010). Despite the novella's apparent existential orientation and social implications, we can pursue an original insight into the relationship between the humanities in general (literature in particular) and the medical field. What has been underplayed so far is an examination of Ivan Ilych's impenetrable illness and the possibly metaphorical employment of this illness to achieve the text's apparent social concern. In other words, we attempt to substantiate the social orientation of existing scholarship on the novella with a considerable examination of Ivan Ilych's illness - possibly a case of cancer metaphorically employed to suggest an evil, dangerous form of life.

\subsection{The Interdisciplinary Approach}

Within this context, Ivan Ilych begins to suffer from an incurable and mysterious ailment when he is about to have what he wants from life. Having secured a good assignment in the legal system and having married and become a father of children, his new life begins to crumble when he falls one day as he is hanging curtains in his new home. His manifest symptoms develop into pain in his left side and a foul taste in his mouth. Despite numerous doctors' visits, Ivan Ilych's physical condition keeps worsening until he dies in agony after much pain and irritable moods. Although his exact illness is never mentioned in the text, this study purports to identify a possible medical condition and relate this to the novella's thematic focus. Critics have pondered the nature of Ivan Ilych's illness. Some have been misled by the text's explicit references to certain diseases or by a devious link the text makes between the protagonist's fall and his illness. As Mary Beard argues, the story remains fiction and the "elusive uncertainty about the nature of his condition is part of the point of the tale," a fact which suggests that we should understand Ivan Ilych's illness metaphorically rather than literally, which, in turn, is part of what we endeavor to do in this article. Moreover, some studies on this text are available in the Russian language most readers cannot access. In addition, some of such studies on the text are dated now since this novella got written and published in the second half of the $19^{\text {th }}$ century, and thus most early studies on it were released before the surge of electronic materials made available to readers through modern technology and the internet. As such, this article re-visits Tolstoy's novella to offer a new reading with fresh perspectives on illness and its employment in literature.

A central goal we seek to accomplish in this article is articulating a description of illness as symptomatic of socio-cultural malaise. Thus, the article looks at illness as treated and contextualized in fiction from a thematic standpoint. For this, we begin with the assumption that prevalent illnesses can characterize certain historical eras, geographical locations, or social classes, as we discuss illness as a metaphor for socio-cultural decline. Hence, the article offers a fresh insight into the interdisciplinary relationship between literature, on one hand, and medicine, on the other, interrogating what medicine can offer for the humanist and what literature can offer for 
the medical practitioner. We as readers can get socially informed messages from the depiction of certain illnesses in literary works and from the prognosis and diagnosis of such illnesses. Moreover, the reactions of patients and their families to illnesses are equally important.

\section{Discussion}

\subsection{Hypocritical Lives}

The Death of Ivan Ilych (1886) is, at its heart, concerned with illness and dying within upper middle-class life. As the story opens, Ivan Ilych, we are told, is dead after having been ill for weeks "with an illness said to be incurable" (p. 172) and for which doctors gave different diagnoses (p. 173), a mystery which immediately establishes the emblematic nature of his medical condition. However, the novella's socially critical thrust that allegorizes the protagonist's illness and prevalent apathy is evident from the start. Ivan Ilych dies miserably following a boring life of civil service. His work associates, in turn, think about "the changes and promotions it might occasion among themselves or their acquaintances" (p. 173). Moreover, his friends are bothered by the "very tiresome demands of propriety" requiring them to attend "the funeral service" and pay "a visit of condolence to the widow" (p. 173). Even so, they are relieved that it is Ivan Ilych who died not them (p. 173). Some of them are not willing to skip a game of cards on the evening of the funeral day (p. 175). Praskovya Fëdorovna, Ivan Ilych's wife, worries about the price of the cemetery plot (p. 176) and discusses with a friend, Peter Ivanovich, how to extract from the government more money for a pension (p. 177). In such a fake world of appearances and sentiments, apathy is hardly surprising and a wretched death becomes a common reality.

In the midst of this life-sucking atmosphere, it is Gerasim — the butler's assistant-who is "a healthy peasant" with "strong hands" and who accepts his master's death as "God's will", saying that "We shall all come to it one day" (p. 177) in response to a note of condolence from Peter Ivanovich. He is more real in this world of fake propriety. Gerasim gives the dying Ivan Ilych the care he needs. Harvey Max Chochinov (2006) (in an elaboration of the knowledge and skills necessary for recognizing and addressing existential, psychosocial, and spiritual aspects of patients' dying experiences) argues: "Within the field of palliative care, developing compassionate and effective responses, which are individually tailored and sensitive to a patient's fluctuating deteriorating health status, is a critical challenge" (p. 100). As compared with the decay of his master's body, Gerasim stands for force and vitality. His presence in the novella is not simply significant because he gives a counterpart to an artificial life; rather, he helps us establish the symbolic nature of Ivan Ilych's illness. The contrast between the lifestyles led by Gerasim and Ivan Ilych highlights the social ramifications of the novella whereby a lifestyle can blight members of a certain class.

In the course of the novella, Ivan Ilych's life is negatively described as the "most simple and most ordinary and therefore most terrible" (p. 178), though he is a member of the upper class. The attitudes and values of such a class are criticized on many occasions in the story. Conformity and imitation are particularly criticized: "Neither as a boy nor as a man was he a toady, but from early youth was by nature attracted to people of high station as a fly is drawn to the light, assimilating their ways and views of life and establishing friendly relations with them" (p. 178). Ivan Ilych lives by the standards of such a class, never questioning its "correct" behavior or simply not thinking about what he deems improper. The medallion he wears on his watch-chain is significantly inscribed with "respice finem", a Latin expression meaning consider the end (p. 179), which Ivan Ilych tried to deny throughout his life. He lived his life "among people of the best society and consequently with the approval of people of rank" (p. 179), wearing fashionable clothes, attending first-class restaurants, and using the best toilet appliances (p. 179). In his work as an examining magistrate, he observes prescribed formalities and decorous ways (p. 180). In brief, the story develops the protagonist's "wrong" or bad lifestyle before we are introduced to his terminal illness. If Ivan Ilych married, it is because "his social circle approved of the match" (p. 181), not because he loved Praskovya Fëdorovna. Ivan Ilych wrongly assumed that getting married was "the right thing by the most highly placed of his associates" (p. 181). However, he is soon dismayed by this experience as matrimony is not "always conducive to the pleasures and amenities of life" but rather an infringement on "both comfort and propriety" (p. 181). Therefore, he begins to find an escape in his official duties away from a stifling marriage that did not offer him emotional fulfillment. His personal and professional life becomes, often unwittingly for him, a risk factor for a serious illness resulting from bad lifestyle habits, assumptions, and values.

\subsection{Personal Pain vs. Social "Ills"}

In fact, Ivan Ilych's life of civil service parallels his life as a sick man; he feels irritable not only when he becomes ill but in work-related scenarios as well. Before his real illness, he would become irritable when he does not get the post of presiding judge and when he is passed over by his superiors for some appointments and promotions and quarrels with them over this (p. 183). This is followed by feelings that his salary is not sufficient 
and that he lives in debt because of "living beyond his means" (p. 183). To save money, he leaves one summer for the country only to experience "ennui for the first time in his life" as well as "intolerable depression" (p. 183) This life of boredom sucks energy out of him and drains his powers just like illness, as we will see. For example, the sleeplessness associated with illness is echoed here when it comes to worrying about securing a good position: "Having passed a sleepless night pacing up and down the veranda, he decided to go to Petersburg and bestir himself, in order to punish those who had failed to appreciate him and to get transferred to another ministry" (p. 183). This is a form of "ill humor" rather than illness, but it seems ultimately linked to it. Ironically, "his life was regaining its due and natural character of pleasant lightheartedness and decorum" (p. 184) as he secured a better-paying position. As we shall see, Ivan Ilych's concern with materialism and secular gains would stifle him and lead to his demise. His self-deception turns out to be as fatal as his presumed illness.

Admittedly, Ivan Ilych "sickened" long before he actually realized due to the sick life he was leading. However, one day he hits his side against a knob in a window frame when he slips while hanging curtains. There is a simple bruise and some pain, but he feels well after that. He is occupied with furnishing a new home and giving it an aristocratic look and relocating the furniture. A sudden fall seems to trigger his downfall: "Once when mounting a step-ladder to show the upholsterer, who did not understand, how he wanted the hangings draped, he made a false step and slipped, but being a strong and agile man he clung on and only knocked his side against the knob of the window frame. The bruised place was painful but the pain soon passed, and he felt particularly bright and well just then." (p. 185). It is with time that he begins to have a strange taste in his mouth and discomfort in his left side. The text suggests, in a way, a relationship between the fall and his subsequent death either by way of making an ironic contrast between Ivan Ilych's aspirations and his ignominious death to come or by way of diverting our attention from the real causes of Ivan Ilych's illness - most probably being the wrong form of life rather than a mere fall. In a life of conformity and imitation of others, Ivan Ilych wants to give the impression to being rich. He wants to be superior and different, but he is actually imitating others. "His house was so like the others that it would never have been noticed, but to him it all seemed to be quite exceptional." (p. 185). His fall coincides with the beginning of a new life in a new house. He assumes his fall is "only a bruise" and that he "merely knocked" himself but this fall would prove fatal. He begins to be irritable in his new home since any slight disturbance to the arrangement of things bothers him. Although it might be a post hoc fallacy to assume that the fall causes his ultimate death, part of the irony of the story is that his new home and its furniture make his life even worse.

At one level, Ivan Ilych's illness seems visceral and real. Irritability and pressure in Ivan Ilych's side aggravate. The first doctor assumes it could be a floating kidney, chronic catarrh, or appendicitis. He also asks for a urine test. This initial diagnosis shows that for the doctor what is important is not a question of life or death but rather the cold examination of the nature of the disease as that of "the digestive, respiratory, or urinary system respectively" (Wiseman, 2010). As a result, the medical institution indirectly helps in keeping Ivan Ilych in the dark about the real nature of his ailment. Instead of taking a new direction in his life, he becomes preoccupied with his excretions and pain symptoms per doctors' orders. Another doctor makes another diagnosis. A homoeopathist makes a different diagnosis as well. One doctor who read the story diagnosed the case to us as angina, a chronic one related to the catarrh, mentioned in the text as an inflammation related to the respiratory tract. In fact, blood clots traveling to the lungs in certain types of cancer can make breathing difficult and cause chest pain. The text leaves open the question of Ivan Ilych's exact illness. The pain and queer taste simply get worse, and he loses appetite and strength. He thinks that the floating kidney might get the support it needs and get arrested back in its place with an effort of his imagination. Otherwise, the vermiform appendix might come all right. He hopes for an improvement in his body's absorption and evacuation. But the same dull gnawing pain and loathsome taste in his mouth persist. He sleeps less, becomes weak and emaciated. In a sense, the incurable nature of Ivan Ilych's illness suggests the mystery of a malignant tumor as a deadly disease and a richly metaphorical one in that. Weight loss and lack of appetite relate to the strange taste in Ivan Ilych's mouth and are signs of a digestive problem or a malignant tumor.

Later in the narrative, Ivan Ilych begins to have "a queer taste in his mouth and felt some discomfort in his left side" (p. 187). This pressure is accompanied by increasing irritability and ill humor (p. 187). His temper would often get worse during dinner time (p. 188), which might relate his ailment to the digestive system. If we are what we eat in existential terms, then the foul taste in Ivan Ilych's mouth is metaphorically his very being - a dull being choking him. At another level of meaning, a case of pancreatic cancer comes to mind since this gland is located behind the stomach as part of the digestive system producing enzymes to help digest food in the intestines. In other words, Ivan Ilych's ailment might be located somewhere in the digestive system and related to what he takes in from the outside world. He sees a celebrated doctor once he is confirmed that he is not well, 
but the doctor assumes an indifferent attitude similar to the one he himself assumes in court against the accused person: "The doctor put on just the same air towards him as he himself put on towards an accused person" (p. 188). By contrast, "To Ivan Ilych only one question was important: was his case serious or not?" (p. 188). For the doctor, a close analysis of the case was more important than a question of life or death. The real question was to decide between "a floating kidney, chronic catarrh, or appendicitis" (p. 188). The choice of the word "case" makes Ivan Ilych an accused man like those he deals with in court and an existential character who is trapped in his own life. The doctor uses what is for Ivan Ilych is "complicated, obscure, scientific phrases" (p. 189) and talks sparely. When Ivan Ilych asks about his condition, whether it is serious or not, the doctor simply retorts: "I have already told you what I consider necessary and proper. The analysis may show something more." (p. 189). This lack of communication between doctor and patient exacerbates Ivan Ilych's condition and extends the novella's critical outlook to medical ethics. Moreover, we get to know that Ivan Ilych died from an "incurable" illness (p. 172) that never gets mentioned. The obscenity and secrecy of this case might suggest a case of cancer, but the text never mentions the illness directly. On his way back home, everything is "dismal" and "depressive" around him (p. 189). This lack of assurance on the doctor's side, i.e., his "dubious remarks", makes the pain acquire "a new and more serious significance" and Ivan begins to watch it "with a new oppressive feeling" (p. 189). Once he gets home, he tells his story to his wife and daughter, but the daughter sits "reluctantly" to listen to his "tedious story" while his wife could not hear him to the end (p. 189). A sick man needs emotional support not only from their family members but from medical practitioners as well, and Ivan Ilych gets neither. Both his social life and his professional one have contributed to Ivan Ilych's ailment.

Actually, the story poses many intriguing points for those interested in its medical side and symptom analysis of diseases. Right to the end, Ivan Ilych's illness wavers between the literal and symptomatic/symbolic. At first, the doctor tended to believe that the problem was in the appendix, but the examination of the urine made him change the medicine. In fact, the urine test results contradicted the symptoms (p. 189). It turns out that "what was happening differed from what the doctor had told him, and that he had either forgotten, or blundered, or hidden something from him. He could not, however, be blamed for that, and Ivan Ilych still obeyed his orders implicitly and at first derived some comfort from doing so" (p. 189). If the doctor hid something from Ivan Ilych, it might be cancer as a deadly illness $19^{\text {th }}$ century doctors did not reveal to patients. In such cases, we would deem Ivan Ilych's illness as a physical ailment with a significance of its own. When he would get agitated, as when having problems with his wife or not being successful at work, he would be "acutely sensible of his disease" (p. 190). People and circumstances would aggravate his condition, but he did not ignore them. Here Ivan Ilych's illness acquires new symbolic meanings related to his frustration with his professional and personal life. His condition is made worse by "the fact that he read medical books and consulted doctors" (p. 190), yet he would continually consult them (p. 190). They only increased his fears and doubts. Of course, anxiety for the ill person is as harmful as hypochondria. With days, there is more pain in his side and a stranger taste in his mouth (p. 190). His breath, it seemed to him, "had a disgusting smell and he was conscious of a loss of appetite and strength" (p. 190). This foul taste in his mouth is an indication of something wrong in his body or a change in his health like an inflammation or an infection of a sort. Significantly, cancer treatment with chemotherapy and radiation can result in strange taste in the mouth. In as far as Ivan Ilych is concerned, there is a suggestive link between a digestive ailment and the strange taste in his mouth.

Ivan Ilych could no more deceive himself about getting better or trying doctors and medicine. He became certain of his physical inadequacy as a living being. However, his understanding of his illness is indicative of the metaphorical way in which people understand malignancy in terms of secrecy, mutation and uncontrollable growth within the body. He becomes more aware of "something terrible, new and more important than anything before in his life, was taking place within him of which he alone was aware" (p. 190). On the one hand, he was aware of the misery he caused for his family and their cold attitude toward him. On the other, this "awful, horrible, and unheard-of thing that was going on within him, incessantly gnawing at him and irresistibly drawing him away" (190) is not fully understood by those around him. Therefore, he is lonely and misunderstood. His pain—importantly "a gnawing pain" (p. 191) —is described as a "poison" penetrating his whole being (p. 192). As Susan Sontag (1978) observes in her famous study Illness as Metaphor on the mythology people wave around illnesses like cancer and tuberculosis, the OED used to give an early "figurative meaning of cancer" as anything that "frets, corrodes, corrupts, or consumes slowly and secretly" (p. 10). This consumption of the body in cancer is indicated in the text of the novella by the word "gnawing." The origin of the word- the Greek karkinos and the Latin cancer-literally means crab (Sontag 10). This can be understood in terms of having an illness that claws into the body from inside and destroys its tissues unrelentingly. Ivan Ilych's reference to this "thing" inside him can also be understood metaphorically in the sense that cancer is "degeneration, the body tissues turning to something hard" (Sontag, p. 13). This killing routine and hidden pain made him miserable: 
"And he had to live thus all alone on the brink of an abyss, with no one who understood or pitied him" (p. 192). The word "abyss" is suggestive of the existential plight of Ivan Ilych, a pre-mature death occurring suddenly when he is very oblivious to such an end. There is an allusion here to the intertwined nature of life and death. A bad life is tantamount to the "abyss" of death.

His brother-in-law who visits them and sees the change in Ivan Ilych's looks tells his sister that Ivan is "a dead man" and that she should be able to see that by the look in his eyes since "there's no light in them" (p. 192), an indication of pancreatic cancer actually or a liver problem. Jaundice and yellowing of the eyes is one symptom of pancreatic cancer due to a cancer growing around the bile duct and blocking its function. Obstructive jaundice relates pancreatic malignant neoplasms to digestive problems and nausea and vomiting. In fact, this indicates an advanced stage of pancreatic cancer whereby it spread beyond where it started ("Signs and Symptoms"/ 2015, cancer.org). A metastasized pancreatic tumor can affect the liver or lungs - through blood circulation or the lymph system - and spread around the digestive organs. Pancreatic cancer does not have manifest symptoms in its early stages. It spreads quickly and is rarely detected in its early stages. When this form of malignant tumor begins to cause problems like abdominal or back pain, it is the growth of tumor that causes pressure on nearby organs. Thus, Ivan Ilych's (left side) pain can be understood as an advanced case of malignancy since early pancreatic cancers often have no signs.

Ivan Ilych sees another doctor who thinks that the problem is with the vermiform appendix and Ivan tries through an effort of imagination to effect "that desired improvement" (p. 193) and continues to deceive himself that he is getting better on medicine. However, the pain he has in his left side contradicts the doctor's diagnosis since the vermiform appendix is situated in the lower right side of the abdomen. He feels "the old, familiar, dull, gnawing pain, stubborn and serious. There was the same familiar loathsome taste in his mouth" (p. 193). He thinks of his family and friends in vain, and he allegorizes death - making himself an Everyman being deserted by family and friends when he is dying: "Death. Yes, death. And none of them knows or wishes to know it, and they have no pity for me. Now they are playing." (p. 194) Regardless of the exact nature of Ivan's illness, the idea is a new phase in his life in which he is confronted with illness and the possibility of dying for having had the wrong assumptions and interests in an already ephemeral life. Pain overtakes the reality of his existence. He is emaciated with time and the pain in his side "would begin its own gnawing work" during work all of a sudden (p. 195). If it were a case of cancer, a fall would not have possibly caused this illness. The illness might have been sneaky and latent. It did not show symptoms until it reached an advanced stage as in many cases of cancer. In pancreatic cancer, for example, symptoms may not appear until it is an advanced case, and this kind of cancer causes back and abdominal pain ("MedlinePlus", 2015), again as vaguely experienced by Ivan Ilych in his "left side" without locating its exact source (p. 187). The text constantly juxtaposes Ivan Ilych's "literal" pain/suffering against the "metaphorical" nature of his condition. His aggravating pain is paralleled by his increasingly miserable existence.

The pain makes Ivan Ilych ponder that it is the only true thing and that he could not deliver himself from this overwhelming pain and the ultimate death (p. 196). When he enters the drawing room where he fell, he is soon reminded of his fall, "for he knew that his illness originated with that knock." (p. 196). This should not, however, make us draw a parallel between the fall and subsequent illness. It is in his mind that he establishes this relationship. In his mind, he sees pain as sitting in his side and gnawing at him: "It sits there as before, gnawing just the same!" (p. 196). In the third month of his illness, people are interested in his case only in terms of the post he might vacate or the discomfort he is causing for his family and the suffering he is enduring (p. 196). As his condition worsens, he sleeps less and he is given opium and hypothermic injections for the pain (p. 197). This confirms the incurable nature of his illness and testifies to the helplessness of medical theories in the face of many cancer types, especially in the late $19^{\text {th }}$ century and before the advances in the medical field we have nowadays. In addition, even patients tend to think about their illnesses in metaphorical ways and despite the reality of the pain they feel. In spite of the pain Ivan Ilych feels, he views his illness metaphorically using cancer tropes, as a creature tearing at his body from inside. While pain is real-"gnawing, unmitigated, agonizing" - death is allegorized as "Death" and becomes "the only reality, and always the same falsity" (p. 199) Pain, helplessness, despair, and loneliness augment Ivan Ilych's mental anguish because thoughts of death never leave him as a chronically ill person. The allegorization of Death is in line with our figurative understanding of Ivan Ilych's illness and private suffering.

Furthermore, emaciation/weight loss is one symptom of cancer. One day as he gets up from the commode Ivan Ilych is terrified by his "bare, enfeebled thighs with the muscles so sharply marked on them." (p. 197). But the text continually juxtaposes Ivan Ilych's illness (possibly cancer) against another order of life, a healthier and more sober one represented by the healthy peasant ways of Gerasim - again for an allegorical end: "Health, 
strength, and vitality in other people were offensive to him, but Gerasim's strength and vitality did not mortify but soothed him" (p. 198). Once more, the wrong kind of life he is leading is full of deception and lies. People are hypocritical rather than honest, which is a source of anguish for him: "Those lies-lies enacted over him on the eve of his death and destined to degrade this awful, solemn act to the level of their visitings, their curtains, their sturgeon for dinner-were a terrible agony for Ivan Ilych.” (p.196). Egocentrism makes him the victim of his own secluded life: "Apart from this lying, or because of it, what most tormented Ivan Ilych was that no one pitied him as he wished to be pitied" (p. 199). This hypocrisy, lack of sympathy, and a fake life of appearances is countered by Gerasim who is not bothered by the work he does for his master "because he was doing it for a dying man and hoped someone would do the same for him when his time came" (p. 199). Gerasim - the "lowly" man - offers a healthy counterpart for the "sick" life Ivan Ilych was leading, thus emphasizing the sociocultural significance of illness and the ability of notorious illnesses to condemn social class structures and relations within literary frameworks. Ivan Ilych does not get the required attention from his wife and children. This is one reason why he realizes his wife's hypocritical attitude: "And the thrill of hatred he feels for her makes him suffer from her touch" (p. 201). Their daughter too is young and healthy. She too is "impatient with illness, suffering, and death, because they interfered with her happiness" (p. 202). His need for pity and understanding is answered not by his family members but by Gerasim, a man far below the social class of his master.

The close association between Ivan Ilych's illness and his life style or social circle is manifest when we consider parts of the story concerning crucial events in Ivan Ilych's life: "His marriage, a mere accident, then the disenchantment that followed it, his wife's bad breath and the sensuality and hypocrisy; then the deadly official life and those preoccupations about money, a year of it, and two, and ten, and twenty, and always the same thing. And the longer it lasted the more deadly it became" (p. 205). This "deadly" alliance is as fatal as Ivan Ilych's terminal illness because it causes mental anguish approximate to physical pain. Ivan Ilych's "mental sufferings were due to the fact that one night, as he looked at Gerasim's sleepy, good-natured face with its prominent cheekbones, the question suddenly occurred to him: "What if my whole life has really been wrong"' (p. 207). His life has been meaningless and horrid. The bad breath of his wife is countered by the foul taste is his own mouth. His official life as a judge is also described as "deadly", draining his energy and causing his progression towards terminal illness. In symbolic terms, his wife's bad breath is a sign of the disillusionments associated with social habits while the strange taste in his mouth is suggestive of the nausea and revulsion caused by his own deadly routine life of conformity. Just as illness makes Ivan Ilych consider the wrong life he has been leading and view it alternatively, we as readers can also read his illness as a figure for social shortcomings. The trope of cancer is particularly convenient due to its rich cultural implications.

\subsection{The Epiphany}

Ivan Ilych's life epiphany comes as he uses illness to make sense of his life; he suddenly thinks: "Maybe I did not live as I ought to have done" (p. 205). Yet in his attempts to reason his current miserable life, he would assume that he lived properly and acted correctly (p. 205). He would even want to live each time he has hope for recovery or feel less pain (p. 208). However, he would again feel that he lived for "falsehood and deception" without considering death or proper life (p. 208). It is only when he realizes the falsity of his previous life and accepts the value of real love to his family and sympathy to his child that he is able to accept death and ease his suffering (p. 209). The ending of the story with its assertion of positive values counters the beginning of the story, which emphasizes self-seeking and materialism of bourgeois life. Through love and sympathy, Ivan Ilych can overcome pain and finally embrace death. A little more than three months of misery, woe and sorrow, he wants to die in peace. Suffering both physically and mentally, he is convinced that doctors cannot ease his sufferings (p. 207). Therefore, the moral of the story (i.e., its social message against careerism and hypocrisy) validates our symbolic understanding of Ivan Ilych's illness.

Gerasim is the healthy peasant who counters the malaise of Ivan Ilych's fake, deceptive existence. It is lies and deception that torture him most. He is in a state of despair because of the falsehood around him. For him it is a question of life and death, not simply a floating kidney or appendicitis. He did not live as he should have done. He was dead in life, in the routine of official work, in his pursuit of money. It is his life that has been wrong, not his body. The pain in the chest and suffocation he feels is that of hiding death and following a false life. Gerasim's compassion toward his master "also includes his honesty about Ivan's imminent death" unlike those who deceive him by avoiding this subject or denying it (Urban, 2015, p. 48). Family members and friends as well as doctors evade the real question of whether he is dying. For Gerasim, all of us are dying and we should not be burdened by those dying. Gerasim teaches us the ethics of care and the role of efficient care in alleviating the suffering and pain of the dying. In the words of Urban, Gerasim illustrates to us "the importance of compassionate human presence in the face of human suffering" (p. 49). In fact, the presence of Gerasim should 
be of interest to care givers and physicians. We learn about the importance of literature to the field of medicine not only through the presence of doctors and attempted yet detached diagnosis of a dying man but rather through the compassionate attention showed by Gerasim, which is the counterpart of the doctors' concern with meticulous prognosis.

Indeed, Ivan Ilych himself is complicit in the wrong life he has been leading as a husband, a father, and a judge. He has been detached from his children in his pursuit of wealth and a better position. Moreover, he suppresses his emotional life and accepts a loveless marriage. And he practiced his official duties ruthlessly. The doctors' attitude of "unbearable superiority was not uncommon to Ilych, because it was the attitude he himself assumed before the accused persons in his work as a judge" (Cruz, 2012, p. 272). Moreover, he deceived himself and denied the existence of suffering and death. His insensitivity to others was echoed in the insensitivity of others towards him, including family, friends, and doctors. For Blake Charlton and Abraham Verghese, the story shows "how cultural values may hinder a patient's ability to confront mortality and how unique social barriers inhibit different caretakers' ability to care for a dying patient." Doctors can have negative attitudes towards patients and may seem detached because of time restrictions and rank (Charlton \& Verghese, 2009). So, the story helps in the education of patients as well as doctors. Papadimos and Stawicki argue that the story offers insights into "critical care and palliative medicine" and is a good read as to where and how "end-of-life intervention should occur" in terms of effective communication with the patient, sympathy, and even empathy as well as dealing with patient's despair and denial and the attitudes of those around them. Ivan Ilych's physical deterioration is of interest to doctors and caregivers, but his spiritual epiphany during his dying moments reveals the moral of the story as man's ignorance of the good way of leading one's life and one's late discovery of this ignorance. In fact, his doctors never mention the fall as the cause of his illness or as a trigger agent. It is never considered when it comes to diagnosis. If he dies from this "fall," it is symbolically his blunder of not having seen the true path of his life. His fall is his silly mistake of having lived his life in the wrong fashion, caring about money, furniture, and promotions. His increasing pain testifies to the failure of the medical institution to help him or locate his exact ailment.

\subsection{Cancer Metaphorics}

Hence, and despite the story's appeal to medical practitioners, attentive readers should focus more on the use of illness in the story as a metaphor for the wrong kind of life. Illness in Ivan Ilych's body simply indicates that there is a problem with his lifestyle. And just as death becomes metaphorically treated as a "private black sack" Ivan Ilych struggles against in vain (Lehto \& Stein, 2009, p. 23), so does illness become a metaphor for the wrong life. In brief, attention should be given to the cultural import of Tolstoy's work and its sociocultural depiction/employment of illness to offer commentary on a "lifeless" bourgeois life that sucks life out of people and makes them "sick." The story invites us to think of cancer as Ivan Ilych's illness and a fit a punishment for the wrong kind of life he has been following. There are so many types of cancer with widely different symptoms according to its stage or the body parts it is affecting. However, doctors' asking Ivan Ilych to observe his excretions and asking for urine analysis - since a change in color or frequency might indicate a case of cancer if this persists for many weeks or if stool or urine has blood-encourages a reading of cancer in the novella. For example, pancreatic cancer is characterized by yellowing of the eyes, dark urine, light-colored stool, and abdominal or back pain. Moreover, noticeable weight loss and unexplained pain are other common signs since malignant cells multiply and pressure other organs, nerves, or blood vessels.

Of course, screening tests, biopsies, and scans are essential in the diagnosis, but the trope of cancer is a convenient one considering the middle-class lifestyle the story is exposing. Cancer in the novella seems more of a personality type thing. The relationship between particular illnesses and areas or social types is not uncommon in our metaphorical approach to illness. And such figurative understanding of illness is often aided by certain medical generalizations. In the US, for example, skin cancer is very common while in Japan it is stomach cancer ("MedlinePlus"). In addition, Sontag argues that cancer is "a disease of middle-class life, a disease associated with affluence, with excess" (p. 15). Moreover, and considering the terrible pain Ivan Ilych experienced before his death, cancer is deemed as "excruciatingly painful" and death resulting from it as "spectacularly wretched" (Sontag, p. 16). According to cancer mythology, "it is generally a steady repression of feeling that causes the disease" (Sontag, p. 22). Ivan was unhappily married. In a very brief reference to the story, Sontag argues that Tolstoy's story has been cited "as a case history of the link between cancer and characterological resignation" (p. 23), i.e., Ivan Ilych giving up the desire to live. It is as if Ivan Ilych's lack of satisfaction in his life brought him a curse that is cancer. A lifestyle can be a risk factor for cancer just as diet, inactivity, and location might bring about this disease. 


\section{Conclusion}

When Ivan Ilych died at the age of 45, he had been ill for weeks with in incurable illness. Doctors give different diagnoses of his case. He was emaciated and endured much pain in his last days. So, the story has an overt level of "allegorical" or symbolic didacticism. Sean Fitzpatrick (2013) states that this novella is a "parable representing the mystery that living well is the best way to die well." This emphasizes the social theme of the text and its moralistic tone. Sontag has pointed out that $19^{\text {th }}$ century thinking about illness made illness express the patient's character and a product of a sick will (p. 43). While we can speak of a cancer personality, we can also hint at a relationship between major illnesses and certain eras. For example, the second half of the twentieth century witnessed the spread of AIDS, which began to be attributed to sexual freedom and deviant sexuality. Nineteenth century cancer can also be thought of in terms of industrialization and commercialism, i.e., changing environment and lifestyles. Literary pieces give illness a meaning and value. Hence, they employ it as a trope for something else. In Ivan Ilych's case, illness is a trope for social disarray: the disconnection of family relations, self-seeking careerism, and a deadly preoccupation with appearances and materialism. Regardless of the exact nature of Ivan Ilych's illness or our analysis of its medical name, the point is that his illness indicates something wrong with his body emerging as a reaction to a diseased social class with fake manners and superficial concerns. And while the realism of Tolstoy's novella communicates to us Ivan Ilych's pain because of a serious illness, the social criticism incorporated in the story gives bodily diseases the rich meanings of illnesses. In a word, the nature of Ivan Ilych's illness is as important and intriguing a case as the employment of this illness as a trope for an erroneous, specious and fallacious life is. While both physicians and relations failed to save him, his real cure could probably have been with him. And he made a realization, but it was too late as suggested by the nature of his terminal illness.

\section{References}

Beard, M. (2015). Facing Death with Tolstoy. The New Yorker. Retrieved from http://www.newyorker.com/books/page-turner/facing-death-with-tolstoy

Brombert, V. (2006). The Ambiguity of 'Ivan Ilych'. Raritan, 26(1), 152.

Charlton, B., \& Verghese, A. (2009). Caring for Ivan Ilyich. Journal General Internal Medicine, 25(1), 93-95. http://dx.doi.org/10.1007/s11606-009-1177-4

Chochinov, H. M. (2006). Dying, Dignity, and New Horizons in Palliative End-of-Life Care. CA A Cancer Journal of Clinicians, 56(2), 84-103. http://dx.doi.org/10.3322/canjclin.56.2.84

Cruz, J. (2012). The Doctor-Patient Relationship in Selected Literary Works. Revista Da Associa o Médica Brasileira, 58(3), 272-275. http://dx.doi.org/10.1016/s0104-4230(12)70192-6

Donnelly, J. (2013). Tolstoy's The Death of Ivan Ilych: Satire, Religion, and the Criticism of Denial. Logos: A Journal of Catholic Thought and Culture, 16(2), 73-98. http://dx.doi.org/10.1353/log.2013.0012

Feldman, S. (2004). The Professional Conscience: A Psychoanalytic Study of Moral Character in Tolstoy's. The Death of Ivan Ilych. Journal of Business Ethics, 49, 311-328. http://dx.doi.org/10.1023/B:BUSI.0000021052.57865.7b

Fitzpatrick, S. (2013). The Death of Ivan Ilych by Leo Tolstoy: A Story for All Souls. Crisis Magazine. Retrieved from http://www.crisismagazine.com

Freeman, M. (1997). Death, Narrative Integrity, and the Radical Challenge of Self-Understanding: A Reading of Tolstoy's Death of Ivan Ilych. Ageing and Society, 17(4), 373-398. http://dx.doi.org/10.1017/S0144686X97006508

Lehto, R. H., \& Stein, K. F. (2009). Death Anxiety: An Analysis of an Evolving Concept. Research and Theory for Nursing Practice: An International Journal, 23(1) 23-41. http://dx.doi.org/10.1891/1541-6577.23.1.23

Lezard, N. (2015). The Death of Ivan Ilych / The Devil by Leo Tolstoy - review. The Guardian. Retrieved from http://www.theguardian.com/books/2011/jul/28/tolstoy-death-ivan-ilyich-devil-review

MedlinePlus. (2015). Cancer: MedlinePlus Medical Encyclopedia. Retrieved from www.nlm..nih.gov/medlineplus/ency/article/001289.htm

Papadimos, T. J., \& Stawicki, S. P. A. (2011). The Death of Ivan Ilych: A blueprint for intervention at the end of life. International Journal of Critical Illness \& Injury Science, 1(2), 125-128. http://dx.doi.org/10.4103/2229-5151.84798

Ryken, L. (2013). Life without Meaning: The Death of Ivan Ilych. The Gospel Coalition. Retrieved from 
http://www.thegospelcoalition.org

Signs and Symptoms of Cancer: What are Signs and Symptoms? (2015). Retrieved from http://www.cancer.org Sontag, S. (1978). Illness as Metaphor. New York: Farrar, Straus and Giroux.

Tolstoy, L. (1886). The Death of Ivan Ilych. (trans. Louise and Aylmer Maude). In S. Barnet (Ed.), The Harper Anthology of Fiction (pp. 172-210). New York: HarperCollins Publishers.

Urban, D. V. (2015). Gerasim's Compassion in Tolstoy's The Death of Ivan Ilych. Resuscitating Paideia: Reading Literature for Wisdom, 1(1), 45-50. http://dx.doi.org/10.15385/jrp.2015.1.1.5

Verno, M. (2009). Exact Times and Watches in Leo Tolstoy's The Death of Ivan Ilych. The Explicator, 67(2), 123-125. http://dx.doi.org/10.3200/EXPL.67.2.123-125

Widyaningrum, A., \& Much, K. (2014). Ivan's Self-Deception and Hypocrisy in Leo Tolstoy's The Death of Ivan Ilych. Language Horizon, 2(1). Retrieved from http://ejournal.unesa.ac.id/index.php/language-horizon/article/view/6394

Wiseman, M. C. (2010). Ivan's Transformation and Coming to Terms in Leo Tolstoy's The Death of Ivan Ilych. Student Pulse, 2(3). Retrieved from http://www.studentpulse.com/a?id=219

\section{Copyrights}

Copyright for this article is retained by the author(s), with first publication rights granted to the journal.

This is an open-access article distributed under the terms and conditions of the Creative Commons Attribution license (http://creativecommons.org/licenses/by/3.0/). 